\title{
Expression of adrenomedullin 2/intermedin in human adrenal tumors and attached non-neoplastic adrenal tissues
}

\author{
Ryo Morimoto, Fumitoshi Satoh, Osamu Murakami, Takuo Hirose ${ }^{1}$, Kazuhito Totsune ${ }^{1}$, Yutaka Imai ${ }^{1}$, \\ Yoichi $\mathrm{Arai}^{2}$, Takashi Suzuki ${ }^{3}$, Hironobu Sasano ${ }^{4}$, Sadayoshi Ito and Kazuhiro Takahashi ${ }^{5}$ \\ Division of Nephrology, Endocrinology, and Vascular Medicine, Department of Medicine, Tohoku University Graduate School of Medicine, Sendai, Miyagi \\ 980-8574, Japan \\ ${ }^{1}$ Department of Clinical Pharmacology and Therapeutics, Tohoku University Graduate School of Pharmaceutical Sciences and Medicine, Sendai, Miyagi \\ 980-8574, Japan \\ ${ }^{2}$ Department of Urology, Tohoku University Graduate School of Medicine, Sendai, Miyagi 980-8574, Japan \\ ${ }^{3}$ Department of Pathology and Histotechnology, Tohoku University Graduate School of Medicine, Sendai, Miyagi 980-8575, Japan \\ ${ }^{4}$ Department of Pathology, Tohoku University Graduate School of Medicine, Sendai, Miyagi 980-8574, Japan \\ ${ }^{5}$ Department of Endocrinology and Applied Medical Science, Tohoku University Graduate School of Medicine, 2-1 Seiryo-machi, Aoba-ku, Sendai, Miyagi \\ 980-8575, Japan \\ (Correspondence should be addressed to K Takahashi; Email: ktaka-md@mail.tains.tohoku.ac.jp)
}

\begin{abstract}
Adrenomedullin 2/intermedin (AM2/IMD) is a new member of calcitonin/calcitonin gene-related peptide family. AM is expressed in various tumors including adrenocortical tumors and modulates tumor growth. The AM2/IMD expression has not been studied, however, in adrenal tumors. The expression of AM2/IMD and AM was therefore studied in human adrenal tumors and attached non-neoplastic adrenal tissues by immunocytochemistry (ICC). Immunoreactive (IR)-AM2/IMD was measured by RIA. Furthermore, the expression of AM2/IMD and its receptor components, calcitonin receptor-like receptor (CRLR), and receptor activity-modifying proteins (RAMPs) 1,2 , and 3 mRNA in these tissues was studied by reverse transcription PCR (RT-PCR). ICC showed that AM2/IMD and $\mathrm{AM}$ immunoreactivities were localized in adrenocortical tumors and pheochromocytomas. AM2/IMD and AM immunoreactivities were detected in medulla of attached
\end{abstract}

non-neoplastic tissues, while the degree of immunoreactivity for AM2/IMD and AM in cortices of attached adrenals was relatively weak or undetectable. RIA detected IR-AM2/IMD in adrenal tumors $(0 \cdot 414 \pm 0 \cdot 12$ to $0 \cdot 786 \pm 0 \cdot 27 \mathrm{pmol} / \mathrm{g}$ wet weight, mean \pm s.e.m.) and attached adrenal tissues $(0 \cdot 397 \pm$ $0.052 \mathrm{pmol} / \mathrm{g}$ wet weight). Reverse-phase high-performance liquid chromatography showed one broad peak eluted in the similar position to synthetic AM2/IMD with several minor peaks. RT-PCR showed expression of AM2/IMD, CRLR, and RAMP1, RAMP2, and RAMP3 mRNA in tissues of adrenal tumors and attached adrenal glands. In conclusion, AM2/IMD is expressed in human adrenal tumors and attached non-neoplastic adrenal tissues and may play (patho-)physiological roles in normal and neoplastic adrenals as an autocrine/paracrine regulator.

Journal of Endocrinology (2008) 198, 175-183

\section{Introduction}

Adrenomedullin 2/intermedin (AM2/IMD) is a novel member of the calcitonin/calcitonin gene-related peptide (CGRP) family, which includes calcitonin, CGRP, amylin, and AM (Chang et al. 2004, Roh et al. 2004, Takei et al. 2004a,b). Two independent research groups first identified this peptide almost simultaneously by genomic searching, naming it AM2 (Takei et al. 2004a) and IMD (Roh et al. 2004) respectively. CGRP, $\mathrm{AM}$, and AM2/IMD activate calcitonin receptor-like receptor (CRLR)/receptor activity-modifying protein (RAMP) system to transduce their signals; AM2/IMD interacts with CRLR/ RAMP1, RAMP2, or RAMP3 non-selectively, whereas
CGRP preferentially interacts with CRLR/RAMP1 and AM with CRLR/RAMP2 or RAMP3 (Roh et al. 2004).

It is well known that adrenal medulla and pheochromocytomas express various neuropeptides and vasoactive peptides, such as neuropeptide Y (NPY) and AM, and their receptors (Hinson et al. 2000, Spinazzi et al. 2005). Moreover, there is accumulating evidence showing production and secretion of these peptides from adrenal cortex and adrenocortical tumors (Takahashi et al. 2002). Among these peptides, AM has been thoroughly studied to show the mitogenic effects on adrenocortical tumor cells and the regulatory actions in secretion of adrenocortical steroids and adrenomedullary catecholamines (Hinson et al. 2000). Recently, we have reported the presence of immunoreactive (IR)-AM2/ 
IMD in human tissues including hypothalamus, pituitary, heart, and kidney by RIA and immunocytochemistry (ICC; Takahashi et al. 2006, Morimoto et al. 2007a). There have been no reports, however, on the expression of AM2/IMD in human adrenal tumors and adrenal glands.

We, therefore, studied the expression of AM2/IMD, along with AM, in human adrenal tumors and attached non-neoplastic adrenal tissues by ICC. We then studied the expression of IR-AM2/IMD in these tissues by RIA with chromatographic characterization. We also studied the expression of AM2/IMD, CRLR, and RAMP1, RAMP2, and RAMP3 mRNA by reverse transcription PCR (RT-PCR).

\section{Materials and Methods}

\section{Subjects and tissues}

This study was approved by the Ethics Committee of Tohoku University School of Medicine, and informed consent was obtained from each patient before collection of tissue specimens examined in the present study.

Tissues were obtained at surgery from patients with adrenal tumors. Immediately after surgical removal, the tissues were fixed in $4 \%$ formalin and embedded into paraffin for ICC or frozen and stored at $-80{ }^{\circ} \mathrm{C}$ before extraction of peptides and RNA. Adrenal tumor tissues employed for ICC, RIA, and RT-PCR were summarized in Table 1. Adrenocortical carcinomas were histologically diagnosed based upon the criteria proposed by Weiss (Weiss 1984, Weiss et al. 1989). All surgical specimens, except for adrenocortical carcinomas, contained attached tissues of morphologically normal adrenal glands. Morphologically normal, non-neoplastic, attached adrenal tissues were obtained for RIA from 23 patients with adrenocortical adenomas, cortisol-producing adenomas ( $n=13$, two males and eleven females, 32- to 75-year old), and aldosterone-producing adenomas $(n=10$, five males and five females, 40- to 71-year old), and for RT-PCR from 4 patients with aldosterone-producing adenomas (two males and two females, 44- to 67-year old).

\section{Antiserum}

The antisera against human AM2/IMD and AM were raised in our laboratory, and their detailed properties were previously reported (Satoh et al. 1996, Morimoto et al. 2007a). The antiserum against human AM2/IMD was characterized by RIA, yielding cross-reactivities of less than $0 \cdot 001 \%$ with other peptides including human AM, CGRP, calcitonin, and amylin (Morimoto et al. 2007).

The antiserum against human AM (no. 102-94921) showed cross-reactivities of less than $0.001 \%$ with other peptides including human AM2/IMD, CGRP, calcitonin, and amylin (Satoh et al. 1996).

\section{Immunocytochemistry}

ICC was performed by the ABC method using the Vector ABC kit (Vector Laboratories, Burlingame, CA, USA), as reported previously (Satoh et al. 1996). The antisera against human AM2/IMD and human AM were used at dilutions of 1:4000 and 1:2000 respectively.

In negative controls, AM2/IMD antiserum preabsorbed with synthetic human $\mathrm{AM} 2 / \mathrm{IMD}_{1-47}, \mathrm{AM}$ antiserum preabsorbed with synthetic human $\mathrm{AM}_{1-52}$, and normal rabbit serum (at a dilution of 1:4000) were used instead of the AM2/IMD antiserum or AM antiserum. Absorption tests were performed using the antisera incubated with synthetic human $\mathrm{AM} / \mathrm{IMD}_{1-47}(10 \mathrm{nmol}$ peptide/ml diluted antiserum) or synthetic human $\mathrm{AM}_{1-52}(10 \mathrm{nmol}$ peptide $/ \mathrm{ml}$ diluted antiserum) for $20 \mathrm{~h}$ at $4{ }^{\circ} \mathrm{C}$ before use.

Intensity of immunostaining in the cells was evaluated on a scale of negative, weakly positive, and positive. In our preliminary experiment, the prominent immunoreactivities for AM2/IMD and AM were observed in all benign adrenocortical tumors examined. We defined this intensity as 'positive'. Negative controls using normal rabbit serum instead of appropriate antibodies showed no immunoreactivity. When immunoreactivity was undetected like negative controls using normal rabbit serum, we described it as 'negative'. The immunoreactivity that should be classified between 'positive' and 'negative' was defined as 'weakly positive'.

Table 1 Adrenal tumor tissues for immunocytochemistry (ICC), RIA, and reverse transcription PCR (RT-PCR) analysis

\begin{tabular}{|c|c|c|c|c|c|c|}
\hline \multirow[b]{3}{*}{ Aldosterone-producing adenomas } & \multicolumn{2}{|l|}{ ICC } & \multicolumn{2}{|l|}{ RIA } & \multicolumn{2}{|l|}{ RT-PCR } \\
\hline & $N$ & Age (yo) & $N$ & Age (yo) & $N$ & Age (yo) \\
\hline & $8(4,4)$ & $34-68$ & $8(4,4)$ & $40-67$ & $4(3,1)$ & $52-61$ \\
\hline Cortisol-producing adenomas & $8(1,7)$ & $41-78$ & $13(2,11)$ & $32-75$ & $4(2,2)$ & $38-60$ \\
\hline Adrenocortical carcinomas & $17(6,11)$ & $18-65$ & $5(1,4)$ & $41-69$ & $4(1,3)$ & $49-69$ \\
\hline Pheochromocytomas & $8(4,4)$ & $26-68$ & $5(3,2)$ & $29-58$ & $7(5,2)$ & $29-64$ \\
\hline Total & 43 & & 31 & & 20 & \\
\hline
\end{tabular}

$N$, number of cases; yo, year old; N/A, not applicable. Two numbers in the parentheses showed the number of male and female cases respectively. 
Peptide extraction and RIA

Tissues were extracted, as reported previously (Morimoto et al. 2007). Briefly, the tissue ( $750 \mathrm{mg}$ ) was boiled in $2 \mathrm{ml}$ of $1 \mathrm{~mol} / \mathrm{l}$ acetic acid for $10 \mathrm{~min}$. To each sample, $8 \mathrm{ml} 50 \%$ methanol in $0.5 \mathrm{~mol} / \mathrm{l}$ acetic acid were added and the tissue was homogenized. The homogenate was centrifuged at $15000 \mathrm{~g}$ for $30 \mathrm{~min}$. The supernatant was separated, dried by air, reconstituted in assay buffer $(0 \cdot 1 \mathrm{~mol} / 1$ phosphate buffer $(\mathrm{pH}$ $7 \cdot 5$ ) containing $0 \cdot 1 \%$ (wt/vol) BSA, $0 \cdot 2 \%$ (vol/vol) Triton $\mathrm{X}-100$, and $0 \cdot 1 \%$ (wt/vol) sodium azide), and assayed.

The RIA of human AM2/IMD was performed as reported previously (Morimoto et al. 2007). Human AM2/IMD ${ }_{1-47}$ (Peptide Institute) was used as a standard. [ $\left.{ }^{125} \mathrm{I}\right] \mathrm{AM} 2 / \mathrm{IMD}_{1-}$ ${ }_{47}$ (Phoenix Pharmaceuticals Inc., Belmont, CA, USA) was used as a radioligand.

Chromatographic characterization of tissue extracts was performed by reverse-phase high-performance liquid chromatography (HPLC) using a $\mu$ Bondapak C18 column $(3.9 \times$ $300 \mathrm{~mm}$, Waters). The tissue extracts were re-extracted with Sep-Pak C18 cartridges (Waters Corp., Milford, MA, USA). The extracts were reconstituted in $0 \cdot 1 \%$ ( $\mathrm{vol} / \mathrm{vol}$ ) trifluoroacetic acid (TFA) and loaded onto the column. The HPLC was performed with a linear gradient of acetonitrile containing $0 \cdot 1 \%$ (vol/ vol) TFA from 10 to $60 \%$ at a flow rate of $1 \mathrm{ml} / \mathrm{min} \cdot$ fraction over $50 \mathrm{~min}$. Each fraction $(1 \mathrm{ml})$ was collected, dried by air, reconstituted with assay buffer, and assayed. To prepare AM2/IMD ${ }_{1-47}$ with oxidized methionine, synthetic human AM2/IMD ${ }_{1-47}(2 \mathrm{mmol} / \mathrm{l})$ was incubated with $0 \cdot 3 \%$ (vol/vol) $\mathrm{H}_{2} \mathrm{O}_{2}$ at room temperature for $1 \mathrm{~h}$.

\section{RT-PCR}

Total RNA was extracted from tissues by the guanidine thiocyanate-cesium chloride method. Total RNA $(4 \mu \mathrm{g})$ was denatured at $65{ }^{\circ} \mathrm{C}$ for $5 \mathrm{~min}$ and transcribed at $37^{\circ} \mathrm{C}$ for $60 \mathrm{~min}$ in a reaction mixture $(20 \mu \mathrm{l})$ containing $0.5 \mu \mathrm{g}$ oligo$\mathrm{dT}, 0.5 \mathrm{mmol} / 1 \mathrm{dNTP}$, and 400 units of Moloney murine leukemia virus reverse transcription (BRL, Gaithersburg, MD, USA). The reaction was stopped by heating at $95^{\circ} \mathrm{C}$ for $5 \mathrm{~min}$, diluted with $30 \mu \mathrm{l}$ water and stored at $-20^{\circ} \mathrm{C}$ until PCR analysis. One microliter of the reaction mixture was subjected to PCR. The PCR was performed in a total volume of $20 \mu \mathrm{l}$ containing $0.2 \mathrm{mmol} / 1$ of each dNTP,
$0 \cdot 25 \mu \mathrm{mol} / 1$ of each primer, and $0 \cdot 4 \mathrm{U}$ GoTaq DNA polymerase (Promega Corp).

The sense and anti-sense primers are summarized in Table 2. The primers were designed to contain one intron between the sense and anti-sense primers to exclude a possibility of genomic DNA contaminations. The PCR of AM2/IMD was performed under the following condition; after heating at $95{ }^{\circ} \mathrm{C}$ for $2 \mathrm{~min}$, denaturation, annealing, and elongation were carried out at $95^{\circ} \mathrm{C}$ for $25 \mathrm{~s}, 60^{\circ} \mathrm{C}$ for $30 \mathrm{~s}$, and $72{ }^{\circ} \mathrm{C}$ for $45 \mathrm{~s}$ respectively and the reactions were repeated for 35 cycles, followed by $72{ }^{\circ} \mathrm{C}$ for $5 \mathrm{~min}$. The PCR of CRLR and RAMP1, RAMP2, and RAMP3 was performed under the following condition; after heating at $94{ }^{\circ} \mathrm{C}$ for $2 \mathrm{~min}$, denaturation, annealing, and elongation were carried out at $94{ }^{\circ} \mathrm{C}$ for $15 \mathrm{~s}, 60^{\circ} \mathrm{C}$ for $30 \mathrm{~s}$, and $72{ }^{\circ} \mathrm{C}$ for $60 \mathrm{~s}$ respectively and the reactions were repeated for 30 cycles, followed by $72{ }^{\circ} \mathrm{C}$ for $5 \mathrm{~min}$. RNA samples subjected to PCR without reverse transcriptase reactions were used as negative controls. Amplification products were visualized on a 5\% polyacrylamide gel stained with ethidium bromide, and viewed on a u.v. box.

\section{Statistical analysis}

Data are shown as mean \pm s.E.M. unless otherwise stated. Correlations between the scale of AM2/IMD or AM immunoreactivity and the score of Weiss criteria (Weiss 1984, Weiss et al. 1989) were examined by $\chi^{2}$ test with a cross-table for ordinal variables. IR-AM2/IMD concentrations in adrenal tumors and attached adrenal tissues were compared among groups by one-way ANOVA followed by Fisher's protected least significant difference. The statistical analysis was carried out using JMP software version 6.0 (SAS Institute, Cary, NC, USA), and $P<0.05$ was considered statistically significant.

\section{Results}

\section{Immunocytochemistry}

Results of ICC for AM2/IMD and AM in adrenal tumors and attached adrenal tissues were summarized in Table 3. All tumors examined, both of cortical and medullary origins, showed positive immunostaining for AM2/IMD and AM. The

Table 2 Primers for reverse transcription PCR (RT-PCR) analysis

Sense primer

\section{Gene}

AM2/IMD CCATGGCCCGGATCCCGACG (1-20)

CRLR TGCAAAGTGTCCCAGTTCATTC (1182-1203)

RAMP1 GGGGAGACGCTGTGGTG (286-302)

RAMP2 CCTATCGAAAAGGATTGGTG (300-319)

RAMP3 TGCTCTGCGGTGGGTGTC (111-128)
Anti-sense primer

TCAGCCATAGCTGTGGGGGCT (429-449)

TGTAAGACGCACTACGAAGACC (1791-1812)

ATGCCCTCAGTGCGCTT (556-572)

CATGGTTGTTGAGAAGCTCGT (603-623)

GTGTCGGTGCGTTTGCTG (481-498)
Genbank accession no.

AB121034

NM005855

NM005854

NM005856

AM2/IMD, adrenomedullin 2/intermedin; CRLR, calcitonin receptor-like receptor; RAMP, receptor activity-modifying protein. Numbers in the parentheses showed the nucleotide numbers of each corresponding cDNA. 
Table 3 Number of cases showing the immunoreactivities for AM2/IMD and AM

\begin{tabular}{|c|c|c|c|c|c|c|}
\hline & \multicolumn{3}{|c|}{ AM2/IMD } & \multicolumn{3}{|l|}{ AM } \\
\hline & \multirow[b]{2}{*}{ Tumor } & \multicolumn{2}{|c|}{ Attached adrenal } & \multirow[b]{2}{*}{ Tumor } & \multicolumn{2}{|c|}{ Attached adrenal } \\
\hline & & Cortex & Medulla & & Cortex & Medulla \\
\hline \multicolumn{7}{|c|}{ Aldosterone-producing adenomas } \\
\hline Positive & 8 & 0 & 8 & 8 & 0 & 7 \\
\hline Weakly positive & 0 & 7 & 0 & 0 & 7 & 1 \\
\hline Positive & 8 & 0 & 7 & 8 & 0 & 6 \\
\hline Weakly positive & 0 & 6 & 1 & 0 & 7 & 2 \\
\hline Negative & 0 & 2 & 0 & 0 & 1 & 0 \\
\hline \multicolumn{7}{|c|}{ Non-functioning adenomas } \\
\hline Positive & 2 & 0 & 2 & 2 & 0 & 2 \\
\hline Weakly positive & 0 & 2 & 0 & 0 & 2 & 0 \\
\hline Negative & 0 & 0 & 0 & 0 & 0 & 0 \\
\hline \multicolumn{7}{|c|}{ Pheochromocytomas } \\
\hline Positive & 8 & 0 & 7 & 8 & 0 & 7 \\
\hline Weakly positive & 0 & 7 & 1 & 0 & 6 & 1 \\
\hline Negative & 0 & 1 & 0 & 0 & 2 & 0 \\
\hline
\end{tabular}

AM2/IMD; adrenomedullin2/intermedin, AM; adrenomedullin, N/A; not applicable.

positive ratio of the immunoreactivity for AM2/IMD or AM was not significantly related to either the origins of the tumors (cortical or medullary) or the hormone production (cortisol, aldosterone, or catecholamines). There was no significant difference in the positive ratio of the immunoreactivity for AM2/IMD or AM between benign adrenocortical adenomas (cortisol-producing, aldosterone-producing, and non-functioning adenomas) and adrenocortical carcinomas.

The specificities of the AM2/IMD and AM immunostaining were confirmed by the absorption tests in all types of the tumors. The representative findings of the absorption tests in non-functioning adenomas were shown in Fig. 1: immunoreactivity for AM2/IMD (Fig. 1A) was completely abolished by the absorption with synthetic AM2/IMD (Fig. 1C), but not AM (Fig. 1B). Similarly, immunoreactivity for AM (Fig. 1D) was completely abolished by the absorption with AM (Fig. 1E), but not AM2/IMD (Fig. 1F).

In aldosterone-producing adenomas, AM2/IMD and AM were diffusely immunolocalized in the tumor cells, which were mainly composed of clear cells (Fig. 2A and B respectively). In attached adrenals, immunoreactivity for AM2/IMD was weak (seven cases) or undetectable (one case) in cortical tissues, whereas positive immunostaining was clearly seen in medulla (Fig. 2D). Similarly, AM immunoreactivity was weak (seven cases) or undetectable (one case) in cortical tissues, whereas positive immunostaining was clearly seen in medulla (Fig. 2E). In the seven cases with positive immunostaining for AM2/IMD and AM in attached cortices, immunoreactivities for AM2/ IMD and AM were focally detected in the subcapsular cortices (arrowheads in Fig. 2D and E respectively). Unlike the attached cortices of aldosterone-producing adenomas, those of cortisolproducing adenomas (data now shown), non-functioning adenomas (data not shown), and pheochromocytomas (Fig. 2M and N) did not show such remarkable immunoreactivities for AM2/IMD and AM in their subcapsular cortices. Negative controls using normal rabbit serum showed no immunoreactivities both in the tumor cells (Fig. 2C) and in the attached non-neoplastic tissues (Fig. 2F).

Similarly to aldosterone-producing adenomas, AM2/IMD and AM were immunolocalized in cortisol-producing adenomas and non-functioning adenomas (data not shown).

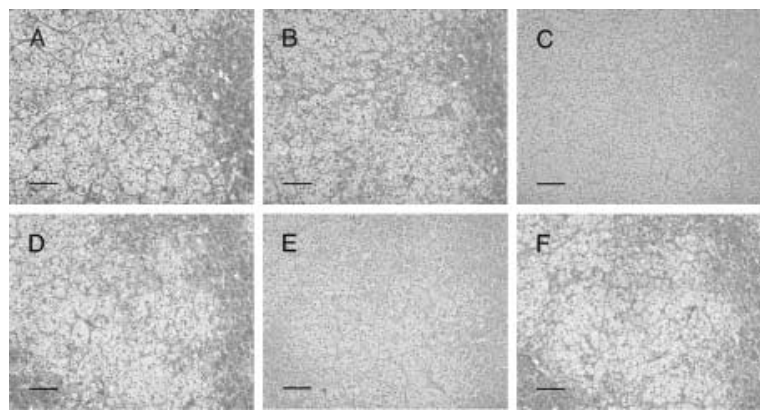

Figure 1 (A and D) Immunocytochemistry for adrenomedullin 2/intermedin (AM2/IMD) and adrenomedullin (AM), (B and E) absorption tests using $\mathrm{AM} 2 / \mathrm{IMD}$ and $\mathrm{AM}$ antiserum preabsorbed with $\mathrm{AM}$, and ( $\mathrm{C}$ and $\mathrm{F}$ ) absorption tests using $\mathrm{AM} 2 / \mathrm{MMD}$ and $\mathrm{AM}$ antiserum preabsorbed with AM2/IMD respectively in nonfunctioning adenoma. Bars, $100 \mu \mathrm{m}$. 

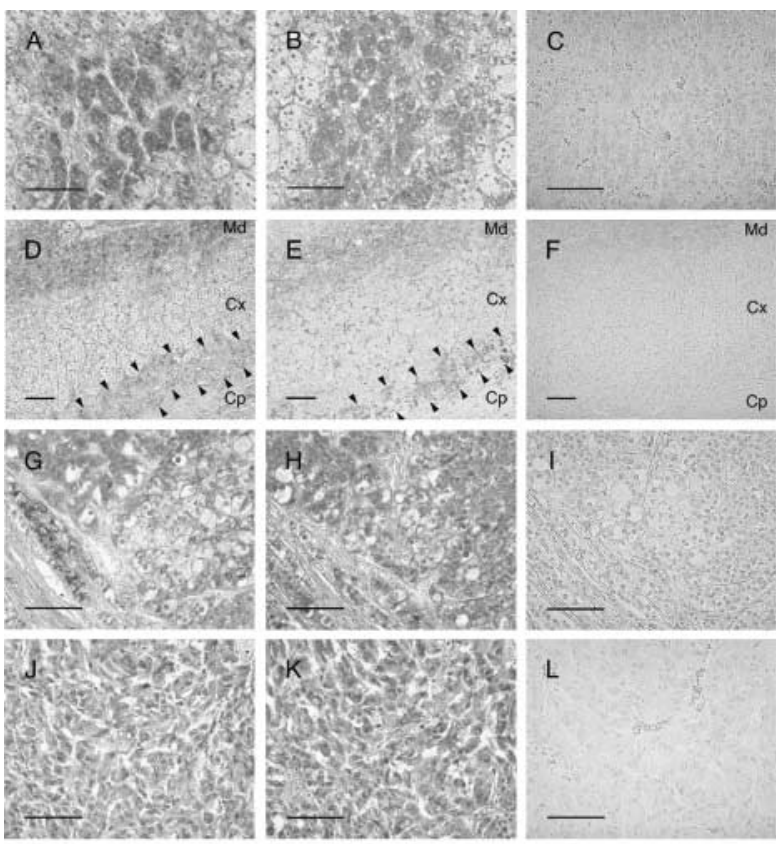

$\mathrm{L}$
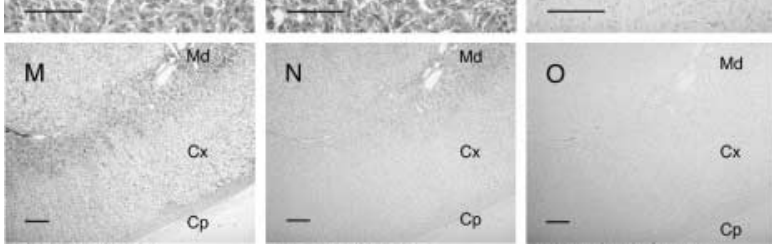

Figure 2 Immunocytochemistry for adrenomedullin 2/intermedin (left panel: A, D, G, J and M) and adrenomedullin (middle panel: B, $E, H, K$ and $N$ ), and negative controls using non-immune rabbit serum (right panel: C, F, I, L and O) in (A-C) aldosterone-producing adenoma, (D-F) attached adrenal tissue of aldosterone-producing adenoma, (G-I) adrenocortical carcinoma, (J-L) pheochromocytoma, and $(\mathrm{M}-\mathrm{O})$ attached adrenal tissue of pheochromocytoma respectively. Cp, capsule; Cx, cortex; $\mathrm{Md}$, medulla. The arrowheads indicate subcapsular cortex, attached to aldosterone-producing adenoma. Bars, $100 \mu \mathrm{m}$ in A through $\mathrm{L}$ and $200 \mu \mathrm{m}$ in $\mathrm{M}, \mathrm{N}$, and $\mathrm{O}$.

In attached adrenal tissues of the tumors, immunoreactivities for AM2/IMD and AM were weak or undetectable in cortical tissues, whereas AM2/IMD and AM immunoreactivities were detected in medulla similarly to the tumors (Table 3).

In adrenocortical carcinomas, AM2/IMD and AM were immunolocalized in the tumor cells of all 17 cases (Fig. 2G and $\mathrm{H}$ respectively). No significant correlations were found between the scale of AM2/IMD or AM immunoreactivity and the score of Weiss criteria ( $P=0 \cdot 2744$ in both analyses). Negative controls using normal rabbit serum showed no immunoreactivity in the tumor cells of adrenocortical carcinomas (Fig. 2I).

In pheochromocytomas, the tumor cells of all eight cases were positively immunostained for AM2/IMD and AM, and representative findings of spindle shape-like tumor cells immunostained for AM2/IMD and AM were shown in Fig. 2J and $\mathrm{K}$ respectively. In attached adrenals, immunoreactivities for AM2/IMD (Fig. 2M) and AM (Fig. 2N) were weakly observed or undetectable in cortices, whereas those for AM2/IMD and AM were detected in the attached medulla with similar degrees to pheochromocytomas (Fig. 2M and $\mathrm{N}$ respectively). Negative controls using normal rabbit serum showed no immunoreactivity in both the tumor cells and the attached tissues of pheochromocytomas (Fig. 2L and $\mathrm{O}$ respectively).

\section{$R I A$}

IR-AM2/IMD was detected in the tumor tissues of cortisolproducing adenomas $(0.572 \pm 0.087 \mathrm{pmol} / \mathrm{g}$ wet weight, $n=13)$, aldosterone-producing adenomas $(0 \cdot 786 \pm 0.27 \mathrm{pmol} / \mathrm{g}$ wet weight, $n=8)$, adrenocortical carcinomas $(0 \cdot 493 \pm$ $0.14 \mathrm{pmol} / \mathrm{g}$ wet weight, $n=5)$, and pheochromocytomas $(0 \cdot 414 \pm 0.12 \mathrm{pmol} / \mathrm{g}$ wet weight, $n=5$; Fig. 3$)$. The IR-AM2/IMD was also present in attached adrenal tissues containing cortex and medulla $(0 \cdot 397 \pm 0 \cdot 052 \mathrm{pmol} / \mathrm{g}$ wet weight, $n=23$; Fig. 3). No significant differences in the tissue concentrations of IR-AM2/IMD were identified among these tumors and attached adrenal glands $(P=0 \cdot 1631)$.

The IR-AM2/IMD in adrenocortical carcinoma (Fig. 4A), pheochromocytoma (Fig. 4B), and attached non-neoplastic adrenal tissues (Fig. 4C) was characterized by reverse-phase HPLC. Reverse-phase HPLC showed that a large amount (more than 65\%) of the IR-AM2/IMD in the tissues was eluted in the similar position to synthetic AM2/IMD, forming a broad peak with multiple shoulders in the 30th-

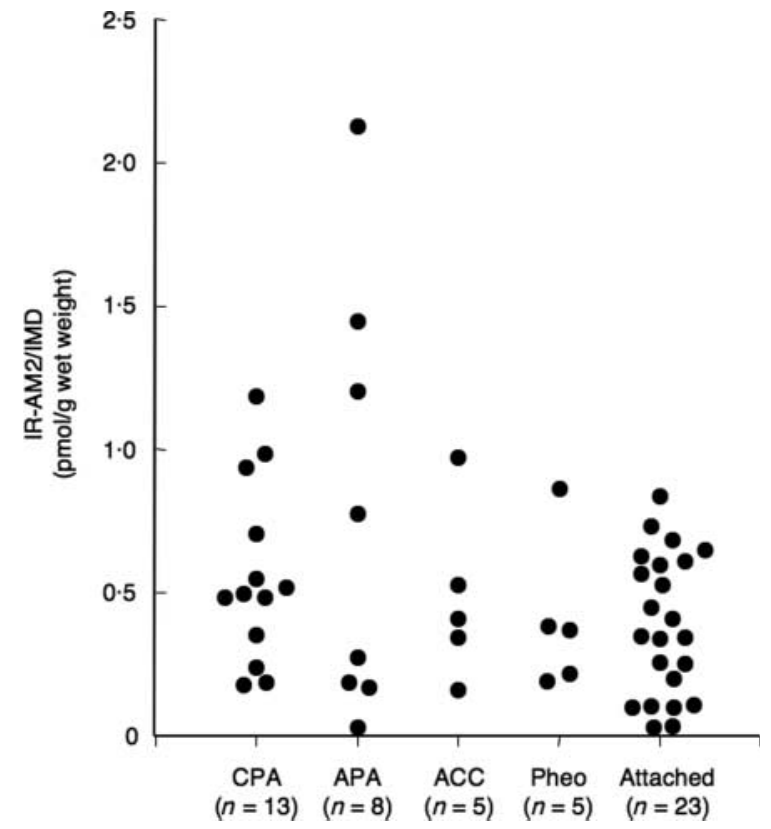

Figure 3 Immunoreactive-adrenomedullin 2/intermedin concentrations in cortisol-producing adenomas, aldosterone-producing adenomas, adrenocortical carcinomas, pheochromocytomas, and attached non-neoplastic adrenal tissues. CPA, cortisol-producing adenomas; APA, aldosterone-producing adenomas; ACC, adrenocortical carcinomas; Pheo, pheochromocytomas; Attached, attached non-neoplastic adrenal tissues. 


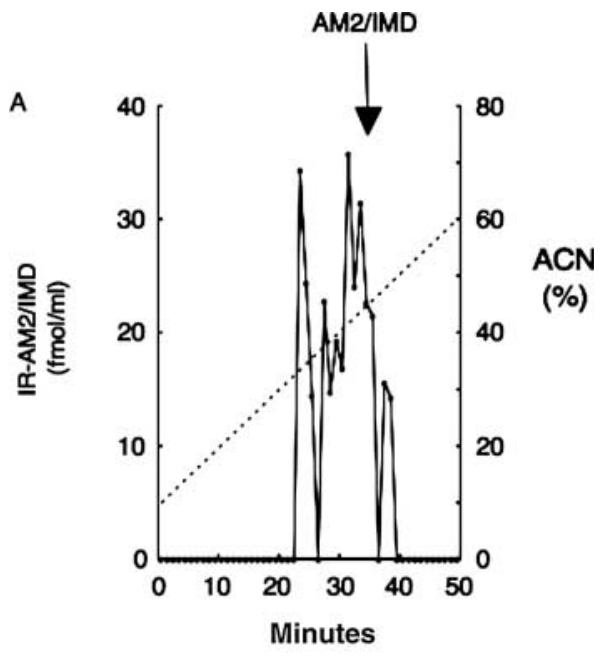

38th fractions (30-38 min; Fig. 4). A peak in the position of 24th fraction $(24 \mathrm{~min})$ was commonly seen in the extracts of all three tissues. Furthermore, one or two smaller peaks were eluted after the position of synthetic AM2/IMD. Oxidized AM2/IMD was eluted in the same fraction as that of authentic AM2/IMD, and synthetic human AM was eluted at the 32nd fraction (32 min; data not shown).

\section{RT-PCR}

RT-PCR analysis showed the expression of AM2/IMD mRNA in tissues of all adrenal tumors examined: cortisol-producing adenomas $(n=4)$, aldosterone-producing adenomas $(n=4)$, non-functioning adenomas $(n=1)$, adrenocortical carcinomas $(n=4)$, pheochromocytomas $(n=7)$, and attached adrenal glands $(n=4$; Fig. 5$)$. In the analysis of AM2/IMD mRNA expression (the first lane in Fig. 5), two RT-PCR products were detected (431 and $449 \mathrm{bp}$ ) due to the insertion/deletion polymorphism of AM2/IMD gene (NCBI refSNP ID rs3840963). No apparent relationship was found between the appearance of these genotypes and the phenotypes of the tissues,

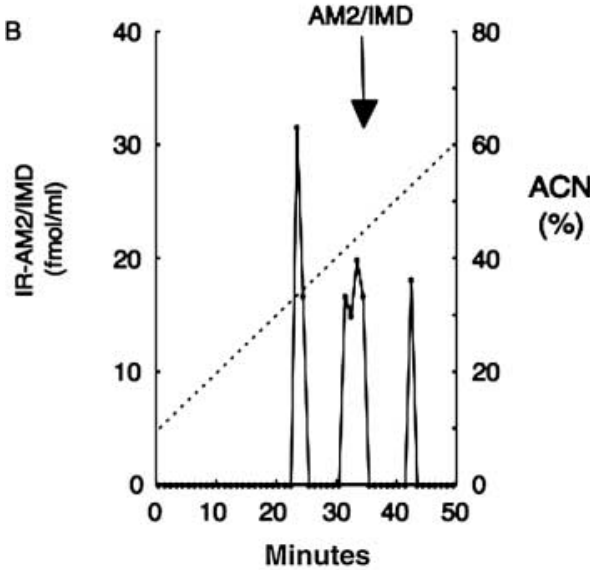
i.e. hormonal function, benign or malignant potential, and neoplastic or non-neoplastic tissues. The expression of CRLR and RAMP1, RAMP2, and RAMP3 mRNA was also identified in all the adrenal tumors and attached adrenal tissues, listed above (Fig. 5). Negative controls without reverse transcriptase reactions gave no bands (data not shown).

\section{Discussion}

The present study is the first study showing the expression of AM2/IMD in human adrenal tumors of both cortical and medullary origins and attached non-neoplastic adrenal tissues. We also demonstrated the expression of CRLR and RAMP1, RAMP2, and RAMP3 mRNA, which are components of the receptor system for AM2/IMD, in these tissues. These results have raised a possibility that AM2/IMD secreted from neoplastic and normal adrenal cells may act as an autocrine/paracrine factor.

It is well known that adrenal medulla and pheochromocytomas produce and secrete various neuropeptides and vasoactive peptides, such as AM, NPY, enkephalin, and somatostatin (Lundberg et al. 1979, Adrian et al. 1983, Hinson et al. 2000, Spinazzi et al. 2005). On the other hand, the knowledge on the pathophysiological roles of adrenocortical regulatory peptides had been limited. There is, however, accumulating evidence that adrenal cortex and adrenocortical tumors secrete certain types of peptides, such as AM, endothelin-1, urocortins, and urotensin II (UII), which may regulate the growth of adrenocortical cells and the secretion of adrenocortical steroid hormones (Takahashi et al. 1998, 2002, Thomson et al. 2001, Albertin et al. 2005, 2006, Fukuda et al. 2005). Recently, we have reported the expression of UII and UII receptor (UT-R) in human adrenal tumors and attached non-neoplastic adrenal tissues by ICC (Morimoto 


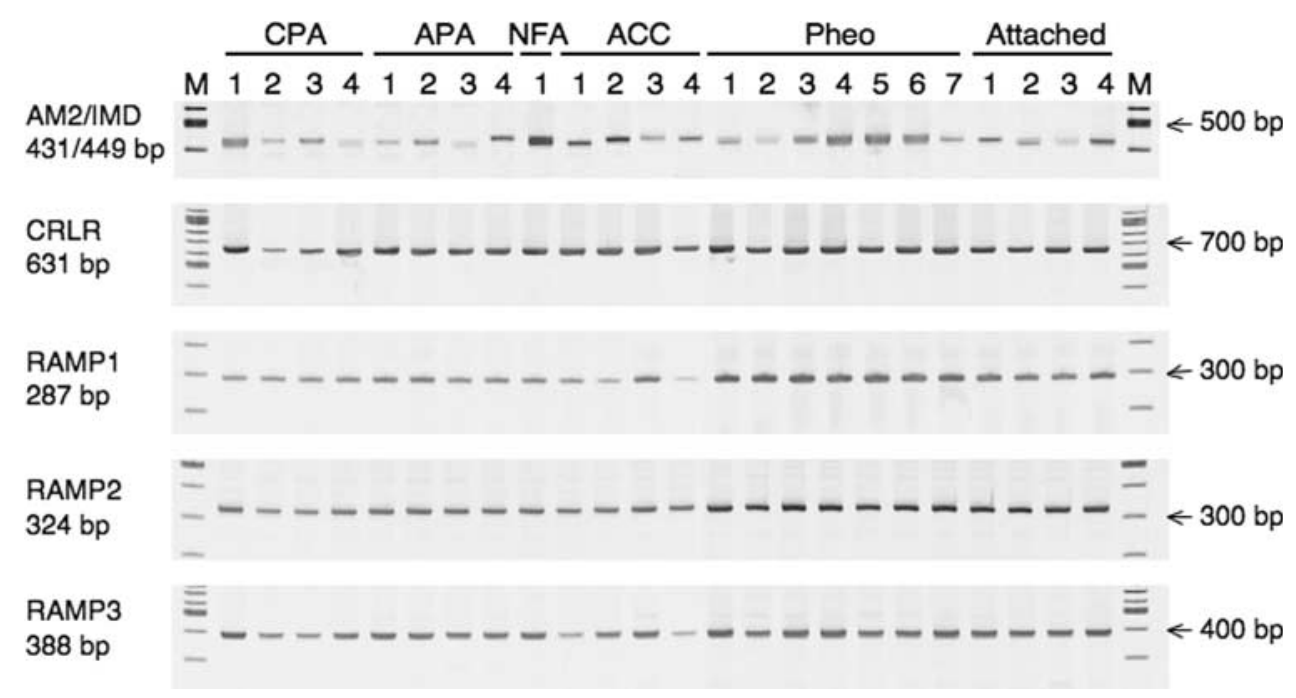

Figure 5 Reverse transcription PCR of adrenomedullin 2/intermedin, calcitonin receptor-like receptor, receptor activity-modifying proteins 1, 2, and 3 mRNA in cortisol-producing adenomas, aldosteroneproducing adenomas, non-functioning adenoma, adrenocortical carcinomas, pheochromocytomas, and attached non-neoplastic adrenal tissues. CPA, cortisol-producing adenomas; APA, aldosterone-producing adenomas; ACC, adrenocortical carcinomas; Pheo, pheochromocytomas; Attached, attached nonneoplastic adrenal tissues; $M$, molecular marker of 100 bp ladder; bp, base pairs.

et al. 2008). In particular, UII immunoreactivity was stronger in the adrenocortical tumors than in non-neoplastic cortices of attached adrenals, suggesting that UII may be related to the regulation of tumor growth in adrenocortical tumors (Morimoto et al. 2008). Similarly to UII, AM was reported to have mitogenic action on adrenocortical cells (Andreis et al. 2000, 2002, Belloni et al. 2001, Nussdorfer 2001, Semplicini et al. 2001, Malendowicz et al. 2003, Rossi et al. 2003) and adrenocortical tumor cells (Albertin et al. 2005). AM2/IMD may have a similar mitogenic action because AM2/IMD shares its receptor systems with AM (Roh et al. 2004).

The present study has demonstrated that the degree of immunoreactivity for AM2/IMD and AM was stronger in adrenocortical tumors than in attached normal cortices. These findings raised a possibility that both AM2/IMD and AM may be related to the tumor growth of adrenocortical tumors as autocrine/paracrine factors, like UII. Furthermore, we also showed stronger immunoreactivites for AM2/IMD and $\mathrm{AM}$ in the subcapsular outer cortices of attached adrenal tissues of aldosterone-producing adenomas, but not other types of adrenal adenomas. It was reported that AM was expressed in the zona glomerulosa cells in rat and human adrenals (Kapas et al. 1998, Kapas \& Hinson 2002, Rebuffat et al. 2002a,b). The present study first showed the expression of AM2/IMD in the human adrenal cortex.

Andreis et al. previously reported that AM attenuated aldosterone secretion from dispersed human adrenocortical cells and aldosterone-producing adenomas in $\mathrm{Ca}^{2+}$-dependent manner (Andreis et al. 1997, 1998, Forneris et al. 2001, Rebuffat et al. 2002b). AM2/IMD and AM expressed at outer cortices of the attached adrenals may attenuate the overproduction of aldosterone from aldosterone-producing adenomas. On the other hand, aldosterone enhanced AM secretion from human aortic vascular smooth muscle cells (Uemura et al. 2002). AM was reported to promote proliferation and inhibit apoptosis of cultured human adrenocortical cells of zona glomerulosa (Rebuffat et al. 2002b). Further studies are required to clarify whether AM2/IMD and AM expressed at outer cortices of the attached adrenals might contribute to the regulation of these pathophysiological processes, such as the hyperplastic changes of zona glomerulosa cells, the so-called 'paradoxical hyperplasia', seen in aldosterone-producing adenomas (Sasano et al. 2004).

Taylor et al. (2005) previously reported that the concentration of IR-AM2/IMD in rat adrenal tissues was below the level of detection by RIA, in contrast to our present report on human adrenal tissues. This discrepancy may be partly attributed to much smaller weights of rat adrenal tissues. Our previous study reported that IR-AM was not detected in $90 \%$ cases of adrenocortical tumors by RIA, in contrast to relatively high expression of AM mRNA by northern blotting (Takahashi et al. 1998). In the present study, however, all adrenocortical tumors showed detectable levels of IR-AM2/IMD by RIA. On the other hand, IR-AM was not detected in the same cases of adrenocortical tumors by RIA (data not shown). This difference between IR-AM2/ IMD and IR-AM contents in the tissues might be explained by the property of AM2/IMD that might be stored in the tumor cells, in contrast to AM (Takahashi et al. 1998).

The AM2/IMD 17-47 antiserum used in the present study was raised in a rabbit by injecting the C-terminal fragment of AM2/IMD, AM2/IMD $17-47$. Roh et al. (2004) showed that $\mathrm{AM} 2 / \mathrm{IMD}_{8-16}$ was essential for the bioactivity of AM2/ 
IMD, whereas AM2/IMD ${ }_{17-47}$ fragment had no biological effects but was functional antagonist of AM2/IMD action. The AM2/IMD antibody used in the present study therefore recognizes the C-terminal portion of AM2/IMD, which may have receptor-binding ability but has no biological activity. HPLC-coupled RIA, however, confirmed that RIA using this antiserum could detect mainly the whole molecule of

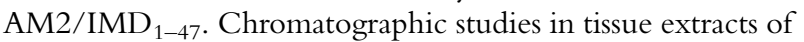
adrenocortical carcinomas, pheochromocytomas, and attached adrenal glands showed IR-AM2/IMD eluted in the position of authentic AM2/IMD, indicating the presence of authentic AM2/IMD in these tissues. On the other hand, the IR-AM2/IMD eluted between the 30th and 38th fractions appears to be multicomponent, and therefore, we could not deny a possibility that other molecular forms of AM2/IMD are present in these fractions. Furthermore, HPLC showed multiple peaks; a peak eluted at the 24th fraction and other minor peaks. These multiple peaks may represent other naturally occurring molecular forms of AM2/ IMD, and artifacts generated during the extraction procedures and/or degradation processes during the tissue harvest, for example acid hydrolysis of Asp-Pro (40-41) bond by the extraction procedure using $1 \mathrm{~mol} / 1$ acetic acid.

In conclusion, we demonstrated that AM2/IMD was expressed in adrenal tumors of both cortical and medullary origins and attached non-neoplastic adrenal tissues. AM2/IMD expression was stronger in tumor cells of adrenocortical tumors than in non-neoplastic portion of attached adrenal cortices. We also showed the expression of AM2/IMD, CRLR, and RAMP1, RAMP2, and RAMP3 mRNA in the adrenal tumors and attached adrenal tissues. These findings suggest that AM2/IMD, as well as AM, may have autocrine/paracrine regulatory roles in adrenal tumors and attached non-neoplastic adrenal tissues, such as tumor growth.

\section{Declaration of Interest}

The authors declare that there is no conflict of interest that would prejudice the impartiality of this scientific work.

\section{Funding}

This study was supported partly by Tohoku University 21st COE Program Comprehensive Research and Education Center for Planning of Drug Development and Clinical Evaluation (CRESCENDO), by a Grant-in-aid for Scientific Research (C) from the Ministry of Education, Science, Sports and Culture of Japan, and by a Research Grant from the Takeda Science Foundation (2005).

\section{References}

Adrian TE, Allen JM, Terenghi G, Bacarese-Hamilton AJ, Brown MJ, Polak JM \& Bloom SR 1983 Neuropeptide Y in phaeochromocytomas and ganglioneuroblastomas. Lancet 2 540-542.
Albertin G, Carraro G, Petrelli L, Guidolin D, Neri G \& Nussdorfer GG 2005 Endothelin-1 and adrenomedullin enhance the growth of human adrenocortical carcinoma-derived SW-13 cell line by stimulating proliferation and inhibiting apoptosis. International Journal of Molecular Medicine 15 469-474.

Albertin G, Casale V, Ziolkowska A, Spinazzi R, Malendowicz LK, Rossi GP \& Nussdorfer GG 2006 Urotensin-II and UII-receptor expression and function in the rat adrenal cortex. International Journal of Molecular Medicine 17 1111-1115.

Andreis PG, Neri G, Prayer-Galetti T, Rossi GP, Gottardo G, Malendowicz LK \& Nussdorfer GG 1997 Effects of adrenomedullin on the human adrenal glands: an in vitro study. Journal of Clinical Endocrinology and Metabolism $\mathbf{8 2}$ 1167-1170.

Andreis PG, Tortorella C, Mazzocchi G \& Nussdorfer GG 1998 Proadrenomedullin N-terminal 20 peptides inhibits aldosterone secretion of human adrenocortical and Conn's adenoma cells: comparison with adrenomedullin effect. Journal of Clinical Endocrinology and Metabolism 83 253-257.

Andreis PG, Markowska A, Champion HC, Mazzocchi G, Malendowicz LK \& Nussdorfer GG 2000 Adrenomedullin enhances cell proliferation and deoxyribonucleic acid synthesis in rat adrenal zona glomerulosa: receptor subtype involved and signaling mechanism. Endocrinology 141 2098-2104.

Andreis PG, Albertin G, Conconi MT, Carraro G, Malendowicz LK, Ziolkowska A \& Nussdorfer GG 2002 Evidence for an autocrine-paracrine role of adrenomedullin in the cultured rat adrenal zona glomerulosa cells. International Journal of Molecular Medicine 10 401-405.

Belloni AS, Albertin G, Forneris ML \& Nussdorfer GG 2001 Proadrenomedullin-derived peptides as autocrine-paracrine regulators of cell growth. Histology and Histopathology 16 1263-1274.

Chang CL, Roh J \& Hsu SY 2004 Intermedin, a novel calcitonin family peptide that exists in teleosts as well as in mammals: a comparison with other calcitonin/intermedin family peptides in vertebrates. Peptides $\mathbf{2 5}$ 1633-1642.

Forneris M, Gottardo L, Albertin G, Malendowicz LK \& Nussdorfer GG 2001 Expression and function of adrenomedullin and its receptors in Conn's adenoma cells. International Journal of Molecular Medicine 8 675-679.

Fukuda T, Takahashi K, Suzuki T, Saruta M, Watanabe M, Nakata T \& Sasano H 2005 Urocortin 1, urocortin 3/stresscopin, and corticotropin-releasing factor receptors in human adrenal and its disorders. Journal of Clinical Endocrinology and Metabolism 90 4671-4678.

Hinson JP, Kapas S \& Smith DM 2000 Adrenomedullin, a multifunctional regulatory peptide. Endocrine Reviews 21 138-167.

Kapas S \& Hinson JP 2002 Adrenomedullin in the adrenal. Microscopy Research and Technique $\mathbf{5 7}$ 91-97.

Kapas S, Martínez A, Cuttitta F \& Hinson JP 1998 Local production and action of adrenomedullin in the rat adrenal zona glomerulosa. Journal of Endocrinology 156 477-484.

Lundberg JM, Hamberger B, Schultzberg M, Hökfelt T, Granberg PO, Efendić S, Terenius L, Goldstein M \& Luft R 1979 Enkephalin- and somatostatin-like immunoreactivities in human adrenal medulla and pheochromocytoma. PNAS 76 4079-4083.

Malendowicz LK, Conconi MT, Parnigotto PP \& Nussdorfer GG 2003 Endogenous adrenomedullin system regulates the growth of rat adrenocortical cells cultured in vitro. Regulatory Peptides 112 27-31.

Morimoto R, Satoh F, Murakami O, Totsune K, Suzuki T, Sasano H, Ito S \& Takahashi K 2007 Expression of adrenomedullin2/intermedin in human brain, heart, and kidney. Peptides 28 1095-1103.

Morimoto R, Satoh F, Murakami O, Totsune K, Suzuki T, Sasano H, Ito S \& Takahashi K 2008 Immunolocalization of urotensin II and its receptor in human adrenal tumors and attached non-neoplastic adrenal tissues. Peptides 29 873-880.

Nussdorfer GG 2001 Proadrenomedullin-derived peptides in the paracrine control of the hypothalamo-pituitary-adrenal axis. International Review of Cytology 206 249-284.

Rebuffat P, Forneris ML, Macchi C, Malendowicz LK, Trejter M \& Nussdorfer GG 2002a Adrenomedullin and its receptors are expressed in the zona glomerulosa of immature and adult rat adrenals: evidences of upregulation of ADM system in immature glands. International Journal of Molecular Medicine 10 85-88. 
Rebuffat P, Forneris ML, Aragona F, Ziolkowska A, Malendowicz LK \& Nussdorfer GG $2002 b$ Adrenomedullin and its receptors are expressed in the zona glomerulosa of human adrenal gland: evidence that ADM enhances proliferation and decreases apoptosis in cultured ZG cells. International Journal of Molecular Medicine 9 119-124.

Roh J, Chang CL, Bhalla A, Klein C \& Hsu SY 2004 Intermedin is a calcitonin/calcitonin gene-related peptide family peptide acting through the calcitonin receptor-like receptor/receptor activity-modifying protein receptor complexes. Journal of Biological Chemistry 279 7264-7274.

Rossi GP, Conconi MT, Malendowicz LK \& Nussdorfer GG 2003 Role of the endogenous adrenomedullin system in regulating the secretion and growth of rat adrenal cortex. Hypertension Research 26 S85-S92.

Sasano H, Suzuki T \& Moriya T 2004 Adrenal cortex. In Endocrine Pathology: Differential Diagnosis and Molecular Advances, 1, pp 211-226. Ed. RV Lloyd. New Jersey: Humana press.

Satoh F, Takahashi K, Murakami O, Totsune K, Sone M, Ohneda M, Sasano H \& Mouri T 1996 Immunocytochemical localization of adrenomedullinlike immunoreactivity in the human hypothalamus and the adrenal gland. Neuroscience Letters 203 207-210.

Semplicini A, Ceolotto G, Baritono E, Malendowicz LK, Andreis PG, Sartori M, Rossi GP \& Nussdorfer GG 2001 Adrenomedullin stimulates DNA synthesis of rat adrenal zona glomerulosa cells through activation of the mitogen-activated protein kinase-dependent cascade. Journal of Hypertension 19 599-602.

Spinazzi R, Andreis PG \& Nussdorfer GG 2005 Neuropeptide-Y and Y-receptors in the autocrine-paracrine regulation of adrenal gland under physiological and pathophysiological conditions (Review). International Journal of Molecular Medicine 15 3-13.

Takahashi K, Satoh F, Sone M, Totsune K, Arihara Z, Noshiro T, Mouri T \& Murakami O 1998 Expression of adrenomedullin mRNA in adrenocortical tumors and secretion of adrenomedullin by cultured adrenocortical carcinoma cells. Peptides 19 1719-1724.

Takahashi K, Totsune K \& Murakami O 2002 Adrenocortical peptides: autocrine or paracrine regulators for the steroid hormone secretion or the cell proliferation? Experimental and Clinical Endocrinology and Diabetes 110 373-380.
Takahashi K, Kikuchi K, Maruyama Y, Urabe T, Nakajima K, Sasano H, Imai Y, Murakami O \& Totsune K 2006 Immunocytochemical localization of adrenomedullin 2 /intermedin-like immunoreactivity in human hypothalamus, heart and kidney. Peptides 27 1383-1389.

Takei Y, Inoue K, Ogoshi M, Kawahara T, Bannai H \& Miyano S 2004a Identification of novel adrenomedullin in mammals: a potent cardiovascular and renal regulator. FEBS Letters 556 53-58.

Takei Y, Hyodo S, Katafuchi T \& Minamino N $2004 b$ Novel fish-derived adrenomedullin in mammals: structure and possible function. Peptides $\mathbf{2 5}$ 1643-1656.

Taylor MM, Bagley SL \& Samson WK 2005 Intermedin/adrenomedullin-2 acts within central nervous system to elevate blood pressure and inhibit food and water intake. American Journal of Physiology. Regulatory, Integrative and Comparative Physiology 288 R919-R927.

Thomson LM, Kapas S, Carroll M \& Hinson JP 2001 Autocrine role of adrenomedullin in the human adrenal cortex. Journal of Endocrinology 170 259-265.

Uemura T, Kato J, Kuwasako K, Kitamura K, Kangawa K \& Eto T 2002 Aldosterone augments adrenomedullin production without stimulating pro-adrenomedullin N-terminal 20 peptide secretion in vascular smooth muscle cells. Journal of Hypertension 20 1209-1214.

Weiss LM 1984 Comparative histologic study of 43 metastasizing and nonmetastasizing adrenocortical tumors. American Journal of Surgical Pathology 8 163-169.

Weiss LM, Medeiros LJ \& Vickery AL 1989 Pathologic features of prognostic significance in adrenocortical carcinoma. American Journal of Surgical Pathology 13 202-206.

Received in final form 23 April 2008

Accepted 6 May 2008

Made available online as an Accepted Preprint

6 May 2008 